\title{
ЗНАЧЕНИЕ ФИЛОСОФСКОГО НАСЛЕДИЯ БЕЛАРУСИ В ФОРМИРОВАНИИ ЦЕННОСТНЫХ ОРИЕНТАЦИЙ СОВРЕМЕННОЙ БЕЛОРУССКОЙ МОЛОДЕЖИ В ПОЛИКУЛЬТУРНОМ ВЗАИМОДЕЙСТВИИ
}

\section{Г. И. ЗАЙМИСТ}

\section{Брестский государственный университет имени А. С. Пушкина, г. Брест, Беларусь}

Развитие философской мысли Беларуси имеет свои особенности. Они предопределены рядом факторов: историческими, геополитическими и социокультурными. Среди них:

- на протяжении длительного исторического времени Беларусь не имела самостоятельной национальной формы государственности;

- на специфику развития не только философской мысли Беларуси, но и других сфер жизни общества оказывал и продолжает оказывать тот факт, что Беларусь находится в пространстве цивилизационного, политического, экономического и культурного взаимодействия Запада и Востока;

- трудности в национально-культурной самоидентификации мыслителей, т. к. некоторые из них в равной степени принадлежат культурам других стран;

- невозможность однозначного соотнесения философских текстов с национальным языком, т. к. они долгое время писались преимущественно на латинском либо польском языках;

- отсутствие национальных тем для философского осмысления, поскольку только со второй половины XIX в. актуализируются понятия белорусской национальности, национальнокультурной идентичности, повышается внимание к статусу белорусского языка и др.;

- становление и последующее развитие философской мысли осуществлялось преимущественно в рамках доминирующих в культуре воззрений - религиозных, просветительских, национально-освободительных, идеологических, что нашло отражение в формулировке проблем, способах их обоснования и решения ведущими белорусскими мыслителями [1].

Однако, несмотря на столь сложные условия и влияния существенных факторов, в философских размышлениях белорусских мыслителей на протяжении всей истории Беларуси содержится глубокий и оригинальный духовный и нравственно-воспитательный потенциал, который, на наш взгляд, требует дальнейшего изучения с учетом современной парадигмальной полифонии и плюрализма философской мысли как формы аккумуляции духовного опыта человека. Однако духовный и нравственно-воспитательный потенциал философского наследия белорусских мыслителей, на наш взгляд, недостаточно востребован в решении образовательных и воспитательных задач.

Начало XXI в. оказалось переломным временем в развитии мировой цивилизации, радикальным трансформациям подвергаются все сферы жизни общества, в эти процессы вступило все человечество. Именно в такие переломные эпохи человечество обращается к переосмыслению традиционных ценностей, накопленных национальными культурами. Особое место в этом процессе занимает философия. Именно философия призвана сегодня дать ответы на ряд вопросов: глобализации и выживания человечества, сохранение национальной культурной идентичности отдельных стран и народов и их интеграции в мировые процессы, выработать действенные модели межкультурного взаимодействия. В данном контексте изучение и бережное сохранение и усвоение национального духовного (в т. ч. философского) белорусского наследия - один из важных ресурсов формирования в процессе образования у белорусской молодежи новых типов поликультурных компетентностей. 
Впервые стратегия формирования поликультурных компетентностей в процессе образования была сформулирована экспертами Совета Европы в 90-е гг. двадцатого столетия в «Европейском проекте» по вопросам образования (Брюссель, 1994 г.) и на симпозиуме «Ключевые компетенции для Европы» (Берн, 1996 г.). В последнем документе поликультурная компетентность понимается как «компетенции, связанные с жизнью в многокультурном обществе - толерантность. Для того, чтобы контролировать проявление (возрождение - resurgence) расизма и ксенофобии и развития климата нетолерантности, образование должно оснастить молодых людей межкультурными компетенциями, такими как принятие различий, уважение других и способность жить с людьми других культур, языков и религий;» [2]. В контекст данной стратегии, на наш взгляд, заложена необходимость формирования нового типа практического гуманизма.

Отличительной чертой философского наследия белорусских мыслителей является чуткое реагирование на ключевые события в жизни народа и отражение культурнополитической истории Беларуси в национальном общественно-политическом творчестве [3]. Главные темы их философских размышлений - это проблемы смысла жизни, соотношение материального и духовного (души и тела), веры и разума, рассматриваемых через призму проблемы человека с позиций гуманизма. В этой главной особенности философских размышлений белорусских мыслителей содержится глубокий потенциал для решения насущных задач и определения перспектив в становлении национального самосознания и формировании гражданско-патриотического мировоззрения белорусов, в т. ч. молодежи. В решении данной задачи особое место принадлежит изучению истории философской мысли Беларуси в процессе образования молодежи. Именно таким образом возможна реализация «нациосозидающей функции философского знания» [4]. В условиях отечественной системы вузовского образования потенциал истории философской мысли Беларуси как обязательной, так и факультативной учебной дисциплины, а также соответствующей интеллектуальной коммуникативной практики, на наш взгляд, должен оказаться более востребованным.

В типовой программе по обязательному модулю «Философия» для учреждений высшего образования, утвержденной Министерством образования Республики Беларусь 30.06.2014, в Модуле 2 «Основные этапы развития философской мысли» предусмотрены всего лишь один вопрос «Философская мысль Беларуси» и требование к компетентности: «Знать основные черты философской мысли в Беларуси». С учетом того, что в целом по модулю 2 на всю историю философии предусмотрено 9 часов аудиторных и 10 часов самостоятельной работы студента, то становится ясным, что у студентов в лучшем случае сформируется лишь общее представление об уникальности и специфичности философского вопрошания о мире, о философствовании белорусских мыслителей, а о формировании на этой основе у будущих специалистов соответствующих интеллектуальных коммуникативных практик говорить не приходится.

Недостаточно, на наш взгляд, используется и потенциал компонента учреждения высшего образования цикла социально-гуманитарных дисциплин Типовых учебных планов для получения высшего образования для введения и чтения студентам курсов по истории философского наследия белорусских мыслителей. Беглое изучение вопроса показало, что такие курсы (История философской мысли Беларуси, История философской и общественнополитической мысли Беларуси, Национальное самосознание и философия Беларуси и т. п.) читаются лишь в отдельных ВУЗах страны (БГУ, БГУИР, ПГУ и др.).

\section{Заключение}

1. В Беларуси философия имеет глубокие корни и богатое наследие, на протяжении всей многовековой истории страны выступала и выступает в качестве фундаментальной интегративной основы белорусской культуры в целом на основе высоких гуманистических принципов. 
2. Белорусская философская мысль «росла и развивалась на всех этапах существования «философии в Беларуси» как живое, действенное, динамичное течение мышления, непосредственно соединенное с проблематикой национальной реальности» [5], являя, тем самым, пример интегрирующей функции философии на уровне всеобщего и отдельного, универсального и национального.

3. Изучение молодежью в период обучения ценностей белорусской философской традиции окажет положительное влияние на формирование их мировоззренческих и идеологических ориентаций и приоритетов в процессе взаимодействия в поликультурном сообществе.

1. Издания Научно-исследовательской группы в области истории философской и общественно-политической мысли Беларуси Центра историко-философских и компаративных исследований Института философии НАН Беларуси: Гісторыя філасофскай і грамадска-палітычнай думкі Беларусі. У 6 т. Т 1-4. - Мінск : Беларус. навука, 2008 - 2017; Евароўскі, В. Б. Нацыянальная філасофія Беларусі: тэорыя, археалогія, гісторыя, генеалогія, школа / В. Б. Евароўскі ; навук. рэд. Л. Ф. Яўменаў. Мінск : Беларуская навука, 2014. - 559 с.; Малыхина, Г. И., Миськевич, В. И., Габрусь, И. Ф., Кутузова, Н. А., Тарасюк, Я. В., Минеева, А. А. История философской мысли Беларуси [Электронный ресурс] / Г. И. Малыхина, В. И. Миськевич, И. Ф. Габрусь, Н. А. Кутузова, Я. В. Тарасюк, А. А. Минеева. - Режим доступа: https://mybook.ru/author/galina-malyhina/istoriya-filosofskoj-mysli-belarusi/read/. - Дата доступа: 02.10.2020; Философская мысль Беларуси [Электронный ресурс]. - Режим доступа: file:///C:/Users/User/Desktop/Философская мысль Беларуси.html. - Дата доступа: 02.10.2020 и др.

2. Ключевые компетенции для Европы. [Электронный ресурс]. - Режим доступа : http://letopisi.ru/index.php. - Дата доступа : 03.10.2020.

3. Философия, культура и общественная жизнь Беларуси в современных условиях. [Электронный pecypc]. - Режим доступа : https://megalektsii.ru/s6716t2.html. - Дата доступа : 03.10.2020.

4. Философия в национальном и универсальном измерении (мнения ученых) // Философские исследования : сборник научных трудов. - 2017. - Вып. 4. - С. 28.

5. Легчилин, А. А. Белорусская философская традиция: история и современность. [Электронный ресурс] / А. А. Легчилин, И. М. Бобков // Философские науки. - 2016. № 7. - С. 13-28. - Режим доступа : file:///C:/Users/User/Downloads/203-202-1PB\%20(1).pdf. - Дата доступа : 15.10.2020.

Значение философского наследия Беларуси в формировании ценностных ориентаций современной белорусской молодежи в поликультурном взаимодействии.

Рассматривается проблема значимости изучения молодежью в процессе обучения философского наследия белорусских мыслителей для формирования их мировоззренческих ориентиров, ценностных приоритетов во взаимодействии в современном поликультурном сообществе.

The Importance of Belarusian Philosophical Heritage in the Formation Value Orientations of Modern Belarusian Youth in Multicultural Interaction

The problem of the importance of the study of Belarusian thinkers' heritage by the youth for the formation of their worldview guidance, value priorities in interaction in modern multicultural community in the process of teaching is considered in the article. 